DOI: 10.34015/2523-4552.2020.1.03

Удк 343.8

Коваленко В. В., доктор юридичних наук, професор, член-кореспондент Національної академії правових наук України, заслужений юрист України

Махніцька К. Г., аспірант кафедри кримінального права та правосуддя Міжнародного економіко-гуманітарного університету імені академіка Степана Дем'янчука ORCID: 0000-0001-5618-7861

\title{
ФОРМУВАННЯ ПРАВОВИХ ЗАСАД ДІЯЛЬНОСТІ, ПОВ'ЯЗАНОЇ ІЗ ЗАПОБІГАННЯМ ПОТРАПЛЯННЯ ДО ЗАСУДЖЕНИХ, ПОЗБАВЛЕНИХ ВОЛІ, ЗАБОРОНЕНИХ ПРЕДМЕТІВ: ІСТОРІЯ ТА СУЧАСНІСТЬ
}

У статті, на підставі результатів вивчення історичних наукових джерел та нормативно-правових актів, що стосуються запобігання потрапляння до засуджених, позбавлених волі, заборонених предметів, виведені періоди їх виникнення, розвитку та функціонування у сучасних умовах, а також встановлені закономірності їх реалізації у кримінально-виконавчій діяльності України.

Ключові слова: правові засади; запобігання; позбавлення волі; заборонені предмети; засуджений; персонал установ виконання покарань.

В статье, на основании результатов изучения исторических научных источников и нормативно-правовых актов, касающихся предотвращения попадания к осужденным, лишенным свободы, запрещенных предметов, выведены периоды их возникновения, развития и функционирования в современных условиях, а также установлены закономерности их реализации в уголовно исполнительной деятельности Украины.

Ключевые слова: правовые основы; предупреждение; лишение свободы; запрещенные предметы; осужденный; персонал учреждений исполнения наказаний.

Постановка проблеми. Як свідчить практика виконання покарань у виді позбавлення волі, наукові розробки, що в тій чи іншій мірі мали відношення до вивчення питань, пов'язаних із запобіганням потрап- ляння до осіб, які відбували покарання у кримінально-вико-навчих установах закритого типу, заборонених предметів, мають тісний зв'язок 3 правовими реформами та процесом удосконалення кримінально- 
виконавчого законодавства України, який розпочався у зв'язку з здобуттям нашою державою незалежності у 1991 р. та прийняттям у 1996 р. Конституції України.

Особливо актуальною ця проблема нині, коли розпочався новий етап реформування сфери виконання покарань (2017р.) та виникла необхідність наукового супроводу тих заходів, що закріплені у відповідних державних програмах (стратегіях, концепціях та ін.).

Постановка завдання. Виходячи 3 цього, головним завданням даної наукової статті $€$ з'ясування змісту історичних засад запобігання потрапляння до засуджених, позбавлених волі, заборонених предметів, а також виведення на цій підставі періодів їх виникнення, розвитку і функціонування в сучасних умовах та встановлення закономірностей їх реалізації у кримінально-виконавчій діяльності України.

Аналіз останніх досліджень i публікацій. Як показало вивчення наукової літератури, активним пошуком ефективних шляхів і засобів боротьби із зазначеним суспільно небезпечним явищем у місцях позбавлення волі займаються такі науковці, як: В.А. Бадира, О.М.Бандурка, Є. Ю. Бараш, І. Г. Богатирьов, В.В.Василевич, Т. А. Денисова, О. М. Джужа, О. Г. Колб, І. М. Копотун, В. О. Меркулова, А.Х. Степанюк, В. М. Трубников, С. Я. Фаренюк, I. С. Яковець та інші вчені.

Поряд $з$ цим, досі на науковому рівні не визначені закономірності виникнення, розвитку та функціонування правових засад діяльності, пов'язаної із запобіганням потрапляння до засуджених, позбавлених волі, заборонених предметів, що й стало вирішальним при виборі теми наукової статті.

Виклад основного матеріалу. Якщо за основу взяти історикоправовий критерій пізнання досліджуваного у цій роботі явища, то можна вивести наступну періодизацію (типологію) наукових пошуків у даній сфері суспільних відносин:

1. Перший період припадає на 1991-1998 рр., коли органи та установи виконання покарань знаходились у підпорядкуванні МВС України, яке й організовувало нормативноправове забезпечення та реалізацію заходів, спрямованих на запобігання потраплянню до засуджених, позбавлених волі, заборонених предметів.

Особливістю цього періоду є те, що наукові дослідження з означеної проблематики займались фахівці на рівні закритих наукових праць (3 грифом «таємно») або з обмеженим режимом доступу («для службового користування»).

У цьому контексті варто виокремити наукові розробки: О. М. Клюєва та О.Є. Судакова (1996р.), які займались питаннями оцінки ефективності і стимулювання результатів діяльності оперативних підрозділів і підрозділів карного розшуку [1, c. 130-137], що було важливо у контексті удосконалення запобіжної діяльності у місцях позбавлення волі з питань потрапляння до засуджених заборонених предметів. При цьому, слід зазначити, що методологічною основою для проведення досліджень 3 питань оперативно-розшукової діяльності (ОРД) стали результати наукових розробок учених радянської доби та зарубіжних фахівців.

Як встановлено в ході даного дослідження, свої особливості мали й 
нормативно-правові акти, які регулювали перелік предметів, виробів і речовин, збереження і використання яких засудженими заборонено. $\mathrm{y}$ першу чергу, мова ведеться про те, що такий перелік аж до 2003 р. (часу прийняття КВК) визначався ВТК України, прийнятому ще у грудні 1970 р. Зокрема, у ст. 28 даного Кодексу «Основні вимоги режиму в місцях позбавлення волі» було зазначено, що перелік і кількість предметів та речей, які засуджені можуть мати при собі, а також порядок вилучення предметів, які заборонено використовувати у виправно-трудових установах, встановлюються Правилами внутрішнього розпорядку виправнотрудових установ.

Враховуючи, що у червні 1996 р. була прийнята Конституція України, у ч. 3 якої було визначено, що засуджений користується всіма правами людини і громадянина, за винятком обмежень, які визначені законом і встановлені вироком суду, а також те, що ст. 28 ВТК залишилась практично незмінною аж до прийняття КВК, навряд чи можна такий законодавчий підхід, що стосується обмежень прав засуджених на рівні підзаконних нормативно-правових актів, визнати правильним.

Як показали результати зазначеного наукового пошуку, саме порушення принципу верховенства права, відповідно до якого норми Конституції України мають найвищу юридичну силу, у першому періоді (1991-1998 рр.) формування правових засад запобігання потрапляння до засуджених, позбавлених волі, заборонених предметів, нерідко ставали однією з детермінант, які обумовлювали вчинення таких правопорушень, як: групова відмова засу- джених від приймання їжі; злісна непокора вимогам адміністрації виконання покарань; дій, що дезорганізують роботу колоній; інші.

Звертає у зв'язку з цим на себе увагу й той факт, що у розділі 11 Основних напрямів реформи кримінально-виконавчої системи в Українській РСР «Удосконалення законодавства про виконання кримінальних покарань», затверджене постановою Кабінету Міністрів Української РСР від 11.07.1991 р. № 88, було зазначено, що з метою укріплення правової регламентації порядку відбування покарання замість Правил внутрішнього розпорядку виправно-трудових установ слід ввести Статут виконання покарань у колоніях та тюрмах Української РСР, у якому встановити повноваження адміністрації та установ, правила поведінки засуджених і форми відповідальності за їх порушення (до речі, це завдання не виконано до сьогоднішнього часу (2020 p.)).

Щодо Правил внутрішнього розпорядку виправно-трудових установ, то цей відомчий нормативноправовий акт був затверджений наказом МВС України від 20.12.1991 р. № 453 та діяв до 1996 р., коли була прийнята нова редакція цих Правил, затверджена наказом МВС України від 08.07.1996 р. № 478, а також наказом МВС України від 22.12.1997 р. № 865. При цьому, у всіх зазначених варіантах цих Правил перелік предметів, виробів і речовин, зберігання яких засудженими було заборонено були незмінними та по суті відображали ті підходи, що були закріплені в аналогічних Правилах, які діяли на території України до 1991 р. [2, с. 82]. Більш того, у жодних зазначених Правилах не було закріплене понят- 
тя «предмети, вироби і речовини, зберігання яких засудженим заборонено», що також виступало однією 3 обставин, яка використовувалась цими особами у ході вчинення протиправних діянь у місцях позбавлення волі.

$\mathrm{У}$ той самий час, у наукових розробках того часу (1991-1998 рр.) ця проблематика також не досліджувалась, хоча певні їі аспекти кримінального, кримінологічного та кримінально-виконавчого характеру учені у загальних рисах у своїх працях розглядали, створюючи таким чином відповідне методологічне підгрунтя для подальших, більш глибоких i системних наукових розвідок у цьому напрямі.

Отже, не дивлячись на високий рівень злочинності та інших правопорушень, а також значну кількість самогубств, членоушкоджень і випадків травматизму серед засуджених у місцях позбавлення волі у першому періоді (1991-1998 рр.), що були у тому числі скорельовані наявністю у цих осіб заборонених предметів (спиртних напоїв, наркотичних речовин, колюче-ріжучих предметів, ін.), на науковому рівні зазначеній проблематиці приділялось недостатньо уваги, а окремі наукові розробки мову про неї вели лише у загальних рисах, створюючи таким чином перспективні умови для подальших пошуків у цьому напрямі.

2. Другий період формування організаційно-правових засад запобігання потраплянню до засуджених, позбавлених волі, заборонених предметів розпочався з утворення у квітні 1998 р. Державного департаменту України з питань виконання покарань, повного його виведення 3 підпорядкування МВС України у березні
1999 р. та завершився прийняттям у липні 2003 р. КВК. При цьому, як показали результати даного дослідження, навіть при внесенні численних змін у чинний на той час ВТК України, суттєво підходи щодо переліку предметів, які було заборонено використовувати у виправнотрудових установах, не змінились, включаючи й на відомчому рівні. Мова, у першу чергу ведеться про Правила внутрішнього розпорядку виправно-трудових установ, які були затверджені наказом ДДУПВП від 06.07.2000 р. № 395/65 та діяли аж до 25.12.2003 р., коли вступили у силу нові ПВР УВП.

Боком обійшли це питання й у постанові Кабінету Міністрів України від 15.2.2002 р. № 167, якою була затверджена Програма подальшого реформування та державної підтримки кримінально-виконавчої системи на 2002-2005 рр., один із розділів якої передбачав вдосконалення законодавчої бази.

Цікавим у зв'язку з цим був і той факт, що у ВТК України з моменту його затвердження у грудні 1970 р. до його відміни на підставі Закону України від 11.07.2003 р. та прийняття КВК, до джерел кримінально-виконавчого законодавства не було віднесено як Конституцію України, так і міжнародні договори, згоду на обов'язковість яких було надано Верховною Радою України, що можна віднести до особливостей правового регулювання другого періоду (19982003 рр.) формування організаційноправових засад запобігання потраплянню до засуджених, позбавлених волі, заборонених предметів.

Отже, як і в попередньому, у другому періоді пріоритетними нормативно-правовими актами, які ре- 
гулювали сферу виконання покарань України, були підзаконні та відомчі правові джерела. I, це при тому, що в п. 14 ст.92 Конституції України 1996 р. було зазначено, що організація діяльності органів та установ виконання покарань визначається виключно законами.

Такий підхід дозволив і в подальшому керівництву ДДУПВП «закривати» очі на проблеми, які виникали у ході виконання - відбування покарання у виді позбавлення волі на певний строк у зв'язку з потраплянням до засуджених заборонених предметів, позаяк статистичні дані з цих питань щорічно залишались незмінними , а також реалізовувати на практиці сформований ще у радянську епоху репресивний підхід на їі вирішення [2, c. 60-83].

Щодо наукових розробок з означеної тематики дослідження другого періоду, то їх зміст у цілому відображає ті тенденції, що склались на протязі 1991-1998 рр., хоча й мав деякі особливості. У цьому сенсі варто виокремити ті наукові праці, що у певній мірі стосувались означеної у цій роботі проблематики та створили відповідні методологічні засади для подальших наукових пошуків у цьому напрямі.

3. Третій період формування організаційно-правових засад запобіжної діяльності з питань недопущення потрапляння в УВП закритого типу заборонених для засуджених предметів розпочався із вступу у законну дію з 01.01.2004 р. прийнятого у 2003 р. КВК та закінчився у грудня 2010 р., у зв'язку з підпорядкування ДКВС України Міністру юстиції. У цьому ж періоді був прийнятий Закон України від 23.05.2005 р. «Про Державну кримінально-виконавчу службу України», а також у грудні
2003 р. - нові ПВР УВП, які у певній мірі впорядкували суспільні відносини, пов'язані із запобіганням потрапляння до засуджених, позбавлених волі, заборонених предметів. Поряд з цим, варто зазначити, що, як і попередні періоди, у третьому часовому відрізку й надалі продовжувались реалізовуватись на науковому, нормативно-правовому, організаційному та інших рівнях ті підходи, що сформувались у так звану радянську епоху та повністю ігнорували права людини і громадянина при виконанні, зокрема, кримінального покарання у виді позбавлення волі [2, с. 6083]. Знову ж таки, закріпивши у главі 2 КВК правовий статус засуджених та відобразивши у ній конституційні положення з цього приводу (зокрема, ч. 3 ст. 63 Основного закону щодо обмежень прав цих осіб тільки на підставі закону та вироку суду), законодавець залишив на розгляд ДДУПВП питання щодо нормативного врегулювання питань, пов'язаних 3 визначенням Переліку предметів, виробів і речовин, зберігання яких засудженими було заборонено. При цьому, слід звернути увагу на те, що визначений у додатку № 9 до п. 29 ПВР УВП перелік заборонених предметів залишився без змін по зрівнянню 3 аналогічними переліками, що були затверджені у ПВР УВП зразка 1991 та 2000 років.

Такий підхід свідчив про те, що ті стереотипи та «перекоси» у відношеннях персоналу органів та установ виконання покарань і засудженими, позбавленими волі, які склались історично та сформувались у виді негативних тенденцій, й надалі були пріоритетними та визначали зміст «реформ»у сфері виконання покарань України, що можна віднести до 
особливостей третього періоду (2004-2010 рр.) формування нормативно-правових засад запобігання потраплянню до засуджених, позбавлених волі, заборонених предметів. Ще однією особливістю зазначеного періоду та, одночасно, закономірністю розвитку досліджуваного у цій роботі явища, було те, що розробкою даної проблематики й надалі більш активно займались учені кримінального права та кримінології, і менш наполегливо та комплексно - фахівці кримінально-виконавчого напряму.

4. Четвертий період формування організаційно-правових засад запобігання потрапляння до засуджених, позбавлених волі, заборонених предметів припадає на 2011-2013 рр., коли ДКВС України з підпорядкування Міністру юстиції у 2010 р. у порядку координації дій 3 іншими державними органами, повністю була підпорядкована Міністерству юстиції України у жовтні 2012 р. I, це при тому, що у квітні 2011 р. у було затверджено Положення про Державну пенітенціарну службу України та на той час діяв Закон України «Про Державну кримінально-виконавчу службу України», відповідно до ст. 1 якого ДКВС України визнавалась центральним органом виконавчої влади, що реалізує державну політику у сфері виконання покарань України.

Звичайно, що при такому «двовладді» та постійній конфронтації (від лат. confrontation - протиборство; протиспівставлення; зіштовхнення) [3, с. 291] зазначених державних органів «руки» до суттєвих видозмін $з$ питань, що стосувались запобігання потраплянню до засуджених, позбавлених волі, заборонених предметів не дійшли, у зв'язку з чим їх кількість, яка вилучалась у цих осіб, щорічно не зменшувалась та відображала ті тенденції, що склались у попередні періоди (1991-2020рр.) [4, с. 6-9]. Таку ж «ваду» носили у той час і наукові розробки, які лише у загальних рисах торкались питань досліджуваної у цій роботі проблематики, зокрема, у контексті змісту режиму виконання та відбування покарання у виді позбавлення волі.

5. П’ятий період формування та розвитку організаційно-правових засад запобігання потрапляння на охороняємі об'єкти УВП та безпосередньо до осіб, які відбували покарання у виді позбавлення волі, розпочався з квітня 2014 р. у, коли був прийнятий Закон України «Про внесення змін до Кримінальновиконавчого кодексу України щодо адаптації правового статусу засудженого до європейських стандартів», та триває по цей час (умовно цей період можна назвати активним та системним реформуванням сфери виконання покарань України, що було обумовлено наслідками Революції Гідності [5]). Зокрема, у зазначений історичний відрізок було прийнято низку нормативно-правових актів, які мали пряме відношення до досліджуваної у цій статті тематики, та створили відповідний перспективний напрям вирішення існуючих проблем запобігання потраплянню до засуджених, позбавлених волі, заборонених предметів на нормативно-правовому, організаційноуправлінському, науковому та інших рівнях, а саме: а) Стратегія сталого розвитку «Україна - 2020», яка була затверджена Указом Президента України від 12.01.2015 р. № 5/2015; б) Стратегія реформування судоустрою, судочинства та суміжних інститутів на 2015-2020 рр. (затвер- 
джена Указом Президента України від 20.05.2015 р. № 276/2015); в) Національна стратегія у сфері прав людини (затверджена Указом Президента України від 25.08.2015 р. № 501/2015); г) Концеп-ція реформування (розвитку) пенітенціарної системи України, яка була схвалена розпорядженням Кабінету Міністрів України від 13.09.2017 р. № 654-р та відмінила таким чином Концепцію державної політики у сфері реформування Державної кримінальновиконавчої служби України зразка 2012 р.; г) ПВР УВП (затверджені наказом Міністерства юстиції України від 28.08.2018 р. № 2823/5); д) інші нормативно-правові акти.

Та, як показали результати даного дослідження, досі незмінними залишились підходи, що стосуються правообмежень засуджених, пов'язаних із закріпленням у ПВР УВП переліку заборонених предметів, виробів і речовин, а також з підвищенням ефективності запобіжної діяльності з означених питань, хоча статистичні дані про їх кількісно-якісні показники свідчать про необхідність їх негайного вирішення, враховуючи значну роль цих предметів у механізмі злочинної поведінки особи [6, с. 17-21].

Щодо наукових досліджень 3 означеної тематики у п'ятому періоді формування та розвитку організаційно-правових і теоретичних засад запобігання потраплянню у місця позбавлення волі заборонених предметів, то і в цьому напрямі тенденції були незмінними - в основному, ці питання розглядались у загальному контексті змісту того об'єкта, який був пов'язаний із сферою виконання покарань України, а саме - порядку виконання та відбування покарань.

Висновки. Отже, результати вивчення нормативно-правових джерел та наукової літератури дозволяють зробити висновок про те, що зазначена тема даного дослідження $є$ актуальною та такою, що має теоретико-прикладне значення, враховуючи те, що досі на доктринальному рівні це питання не розроблялось, а також такою, що обумовлена необхідністю наукового супроводу тих реформ, які здійснюються у сьогоденні у сфері виконання покарань у контексті зобов'язань України 3 питань адаптації іï̈ законодавства до вимог законодавства Європейського Союзу, а також виконання рішень Європейського суду з прав людини та міжнародних конвенцій, згоду на обов'язковість яких надала Верховна Рада України.

\section{Список використаних джерел}

1. Клюєв О. М., Судаков О. Є. Оцінка ефективності і стимулювання результатів діяльності оперативних підрозділів і підрозділів карного розшуку. Вісник університету внутр. справ. 1996. Вип. 1. С. 130-137.

2. Гель А. П., Семаков Г. С., Яковець І. С. Кримінально-виконавче право України : навч. посібник / за ред. проф. А. Х. Степанюка. Київ : Юрінком Інтер, 2008. 624 с.

3. Булыко А. Н. Большой словарь иностранных слов. 35 тысяч слов. Изд. 3-е, исправ., перераб. Москва : Мартин, 2010. 704 с.

4. Про діяльність підрозділів охорони, нагляду і безпеки кримінальновиконавчих установ у 2011 році : інформ. бюлетень. Київ : ДПтС України, 2011. Кн. 1. 69 с. 2014. 122 c

5. Про Майдан 2013-2014 рр. Незламні / уклад. Медвідь В. Луцьк : Твердиня, 
6. Про стан правопорядку, ізоляції та нагляду, діяльність підрозділів охорони, пожежної безпеки та воєнізованих формувань Державної кримінально-виконавчої служби України у 2016 році : інформ. бюлетень. Київ : Департамент Державної кримінальновиконавчої служби Міністерства юстиції України, 2017. 34 с.

\section{References}

Kliuiev, O. M., Sudakov, O. Ye. (1996). Otsinka efektyvnosti i stymuliuvannia rezultativ diialnosti operatyvnykh pidrozdiliv i pidrozdiliv karnoho rozshuku. Visnyk un-tu vnutr. sprav, 1, 130-137 [in Ukrainian].

Hel, A. P., Semakov, H. S., Yakovets, I. S. (2008). Kryminalno-vykonavche pravo Ukrainy. Kyiv: Yurinkom Inter [in Ukrainian].

Bulyko, A. N. (2010). Bolshoi slovar ynostrannykh slov. 35 tysiach slov. Yzd. 3-e, ysprav., pererab. Moskva : Martyn [in Russian].

V. Kovalenko, Doctor of Laws, Professor, Corresponding Member of the National of the Academy of Law Sciences of Ukraine, Honored Lawyer of Ukraine

K. Makhnitskaya, Postgraduate Student of Department of criminal right and justice of International University of Economics and Humanities Academician Stepan Demianchuk

ORCID: 0000-0001-5618-7861

\section{Formation of legal bases for activities related to prevention of penetration of convicted persons deprived of liberty, prohibited items: history and modernity}

In the article, on the basis of the results of studying of historical scientific sources and normative legal acts, concerning prevention of getting to the condemned, imprisoned, forbidden subjects, the periods of their occurrence, development and functioning in modern conditions are deduced, and also regularities of their realization in criminal executive activity of Ukraine.

Practice shows that the execution of sentences in the form of imprisonment, scientific developments that are in one way or another related to the study of issues related to the prevention of entry into the penal institutions of closed type, prohibited subjects, have close connection with legal reforms and the process of improving the criminal law of Ukraine, which began in connection with the gaining of our state independence in 1991 and the adoption in 1996 of the Constitution of Ukraine.

This problem is especially relevant nowadays, when a new stage of reforming the sphere of punishment execution began (2017) and there was a need for scientific support of the measures enshrined in the relevant state programs (strategies, concepts, etc.).

Proceeding from this, the main task of this scientific article was to find out the content of the historical principles of preventing prisoners, deprived of liberty, prohibited objects, as well as to deduce on this basis the periods of their occurrence, development and functioning in modern conditions and to establish regularities of their implementation in criminal-executive activity of Ukraine. 
Thus, the results of the study of regulatory sources and scientific literature allow us to conclude that the topic of this study is relevant and of theoretical and practical importance, given that this issue has not been developed at the doctrinal level, as well as such due to the need for scientific support for the reforms currently underway in the sphere of punishment in the context of Ukraine's obligations to adapt its legislation to the requirements of European Union law, as well as ting the European Court of Human Rights and international conventions ratified by the Parliament of Ukraine.

Keywords: legal principles; prevention; imprisonment; prohibited items; condemned; staff of penal institutions. 